\title{
The Role of Parental Assistance for Children in Social Media Use and Cyberbullying
}

\author{
Primada Qurrota Ayun \\ \{primadaqa.ayu@gmail.com\} \\ Universitas Diponegoro, Indonesia
}

\begin{abstract}
The use of social media by children is common today. The technological developments indirectly affect how children using a gadget. Unfortunately, bullying behaviour on social media is also susceptible to children. For this reason, it is important to have assistance from parents for children to avoid being perpetrators or victims of bullying. The purpose of this research is to find out the role of parental assistance in bullying behaviour on social media. This research is a descriptive qualitative research to analyze events, phenomena, and social conditions. Behaviour is related to both verbal and nonverbal actions done by a person. Cyberbullying is the use of technology to intimidate, victimize, or disturb individuals or groups of people. The form of parental assistance can be in the form of how parents have a good literacy in the media, especially internet media in which people have the ability to access, analyze, and evaluate the strength of images, sounds, and messages.
\end{abstract}

Keywords: Parents Assistance, Cyberbullying, Children

\section{Introduction}

Livingstone [1] said that there were speculations about the "digital generation", children in "information age", "computer nerds", "innocent on the Net", the "digital divide", and "addicted surfers". This concept shows how close today's children are to virtual life. Virtual life can be said to be pseudo-reality which allows them to communicate, make friends and socialize through their gadgets or virtually.

The fact that children today cannot avoid their gadgets is interesting for further study. It can be stated that recently almost all assignments given by the teacher are asked to use the internet as the source of information. In addition, based on the data obtained, the children under 15 years are 10 percent from the total internet users [2].

A survey on behaviour in the internet of 2064 children aged 9-12 years has shown their activities, such as studying, playing games, watching movies or videos, playing social media, buying and selling, reading news, downloading, and listening to songs. Even though it has various positive impacts, the use of gadgets and the internet certainly has negative effects [3].

One of the negative impacts in using internet media is bullying. Unfortunately, parents still don't aware about cases of bullying in the internet, especially social media. That is why it is necessary to have a process of family supervision and parental assistance in providing digital access to their children.

Based on data from the Indonesian Child Protection Commission, the educational cases to 30 May 2018 were 161 cases. It revealed from the data that children as victims of violence and 
bullying reached 22.4 percent, and children as perpetrators of violence and bullying reached 25.5 percent. From 2011 to 2016, there were about 253 cases of bullying, consisting of 122 children as victims and 131 children as perpetrators.

This data is not significantly different from the Ministry of Social Affairs that reported there were 967 cases with 117 cases of bullying in June 2017. UNICEF also reported in 2016 that 41 to 50 percent of adolescents between the ages of 13 and 15 in Indonesia have experienced cyberbullying. According to the social psychologist from Gadjah Mada University (UGM), Koentjoro, social media can influence a person's social behaviour, including bullying. "Social media has big influence in triggering bullying", he explained, as reported by the official UGM website [4].

Social media as one of the most accessed media on the internet has a role in creating bullying. As many as $47 \%$ of students in Pontianak, $42.2 \%$ in Bandung, and 32\% in Surabaya use the internet for entertainment. The use of the internet for social media ranks the second top among the students in these three cities. Meanwhile, the proportion of these two activities (the use of the internet for entertainment and the use of internet for social media) is somewhat reversed for youth in Denpasar. The youth in Denpasar use the internet more to enjoy social media (33 percent) than entertainment (24.6 percent) [5].

This study is intended to determine the form of the parental assistance role for children in the use of social media use and cyberbullying.

\section{Theoretical Framework}

\subsection{Cyberbullying}

Bullying is a complex phenomenon and manifests in different forms according to changes which occur in society. The development of the media has changed the form of bullying, one of which is the form of bullying in cyber media. Hockenburry and Hockenburry [6] explains behavior is an action taken in relation to an object or entity.

According to Willard and quoted by Bernike in Santosa [7], explains that there are several forms that are categorized as cyberbullying as follows; flaming, online harassment, cyberstalking, denigration, masquerade, outing, and exclusion. Flaming is bullying done by sending rude or vulgar messages about someone to an online group or people via email or other text messages. Next type of cyberbullying is online harassment. It is the sending of offensive and repeated online messages via email or other text messages. Cyberstalking is bullying that is carried out in a way that the perpetrator threatens to harm/hurt or intimidate excessively. Denigration is bullying in the form of sending certain statements or materials online that are harmful, untrue, or rude about someone to another. Masquerade (incognito) is virtual bullying in which the perpetrator pretends to be someone else and sends or posts material that makes someone look ugly. Outing is virtual bullying by sending or uploading somebody's material which contains personal, sensitive or embarrassing information, including forwarding personal messages or pictures with the same message content. The last type of bullying is exclusion. It is done by removing or kicking out someone roughly from an online group. 


\subsection{Parental Assistance}

Parents have an important role for their children, both as teachers, guides, mentors, companions, and role models for children. Children and parents should have effective communication in order to create a harmonious relationship. Several forms of effective communication according to Shochib [8] are:

1. The parent ability to convey statements to their children will make them understand and realize what parents feel and want so that they are easy to obey parents.

2. The parent ability to listen to children in a reflective way will help them read, understand and realize what is being done so that they are aware of changing their wrong actions and are aware to optimize their correct behaviour.

3. The parent ability to accept children's feelings means they have been able to understand the world.

4. The parent ability to communicate with humour, especially when the child is anxious, will be able to comfort the child to a normal condition and be ready to accept messages of moral values from parents.

From this explanation, the form of child assistance requires good, harmonious communication so that parents are able to convey statements to their children so that children can understand.

One form of parental assistance can be in the form of how parents have good literacy in media, especially internet media. According to Jefkins [9], media literacy is an ability and skill that a person possesses to understand images and sound, to recognize, to manipulate and change digital media to distribute persuasively and easily adapt it to new forms of media. Media literacy is also defined as individual knowledge and skills in analysing, evaluating, or producing media messages [10].

Media literacy, according to Aufderheide [11], is identified as a movement, which is designed to help the understanding, to produce and negotiate meaning in the multimodal of images, words and sounds. "One's knowledge of media literacy is the ability to decode, evaluate, analyse and produce both printed and electronic media. The basic goal of media literacy is an important autonomous relationship for all media. The emphasis in media literacy training ranges widely, including information of citizenship, appreciation of aesthetics and expression, social advocacy, self-esteem, and consumer competence".

Arnett, Larson and Offer [12] explains that there are two models in media literacy. The first is the protectionist or inoculation model. It is media education to filter access in media content and the media which is considered dangerous, especially for children. Protectionist models for media education promote strategies for critically viewing and increasing parental control over media to children. The second model in media literacy is open-access models. It is considering the importance of personal pleasure in the use of media by individuals and groups, with the belief that the audience, including children, deliberately negotiate meaning and realize that media is constructed for this purpose. The open access model is intended to advance the education which is media literate from a strong freedom of expression, and emphasizes broad access to the use of media as the basic of a democratic society. This model supports relatively limited access to tools, content, and distribution, which has implications for related legal and policy issues such as copyright, systematic media rating, media ownership, and communitybuilding media.

The presence of new media or the internet has made media literacy related to both understanding media content and producing multimedia and interactive text. In addition, literacy is also connected to the very rapid growth of internet use by children and adolescents through 
their interactions with the internet at home [13]. Therefore, the term literacy has changed to become plural, due to the increasing of media use which is convergent and the creation of communication and contemporary media.

\section{Methodology}

This research is a research using qualitative descriptive method. The subjects in this study were parents who used the internet as access to information and had elementary school age children. As many as 3 informants were occupied to explore more about the forms. The data collection technique was done by means of interviews. Esterberg [14] states that a question instrument has been prepared before conducting interview and each respondent gets the same question. The steps used in this research are as follows:

1. Problems and formulation of research questions. The researcher tries to describe the focus of the research by formulating questions in a certain way.

2. Data that produce situations, namely the text of life experiences. The researcher creates descriptive narratives to explain the results of interviews that have been conducted.

3. Data analysis, in the form of implications and interpretations. After the data have been collected based on the results of the interview, the final step that the researcher must take is to read and carefully examine the interview data to reveal the configuration of meaning, both structure and how the meaning is created, from Von Eckartsberg [15].

\section{Results and Discussion}

The results obtained from this study indicate that children have the privilege of accessing the internet every day with a duration of more than three hours a day. They use it to access information and exchange messages via WhatsApp or line. However, as stated by Leung and Lee (2011 in Kurnia [13]), it is revealed that children or adolescents who access the internet have several potential risks because they might meet people who potentially endanger themselves. Those children and adolescents are also exposed to social deviant content and are connected to paedophilia. They are exposed to with pornographic/violent/hateful content too. They are commercially exploited, privacy disturbed, and connected with unwanted people. Those are forms of cyberbullying that accidentally occur and haunt children when accessing the internet. The three informants have interesting answers about the access they provide to their children in using the internet. Things that are interesting for discussion are as follows:

1. Knowledge of cyberbullying

Parents still do not understand the concept of bullying. The second informant, for example, said that the concept of bullying was still unclear. Young children are teased but they feel that it is just a joke. Thus, children think that teasing is a form of joking.

2. The role of parental assistance in using the media

As expressed in the concept above, there are ways of effective communication in parental assistance, namely:

a. It is the parent ability to express opinions to children. In the interview results, it was found that there were parents who were quite protective in giving access to their children, for example, they gave time limits and used their email addresses to provide social media access by discussing with their children. Meanwhile, the first informant 
stated that they gave freedom to children in using social media. They believed in what their children were doing. Open-access models in media literacy consider the importance of personal pleasure in the media use by individuals and groups, with the belief that audiences, including children, negotiate meaning and realize that media is constructed for that purpose. Here, parents play an important role in agreeing or disagreeing with their children when accessing internet media.

b. The parent ability to listen to their children can be seen from the forms of communication carried out by parents in listening to what their children are saying and understanding what is happening. For mentoring children in social media use and bullying, the informants stated that they listened to their children and gave them to be able to tell stories about the problems they experienced.

c. The parent ability to accept children's feelings. This child's feelings are shown by the explanation given by the informants that their child has the ability to tell stories about what they do while surfing the internet. In addition, when parents discuss with their children about how they access the internet and provide internet services, it is a form of how parents accept their child's feelings.

d. The parent ability to communicate with humour. This ability is still considered rare to be happened. They say that they rarely use humour in communicating with their children.

3. The form of mentoring role in the use of social media and cyber bullying

Assisting children in using social media and surfing the internet is something that parents must do at this time. There is the need for parents to be aware about media literacy, and now it has become digital media literacy. Parents at this time are expected to have the ability and skills that someone is able to understand images and sounds, recognize, have the ability to manipulate and change digital media. Some of the roles that are expected to exist in the process of mentoring done by parents in the use of social media and cyberbullying are as follows:

a. Children are given an understanding of what to do and what not to do in social media.

b. There is two-way communication that listening to stories told by children is important.

c. As parents in the millennial era today, they must understand what is trending and follow developments.

\section{Conclusion}

The aim of this research is intended to determine the form of the parental asistance role for children in the use of social media use and cyberbullying. The result of this study showed; the parent needs an understanding of the meaning of bullying, especially cyberbullying. In addition, the parent must also be able express opinion, listen, accept children's feelings, and communicating with their children.

\section{References}

[1] S. Livingstone, Young people and new media: Childhood and the changing media environment. Sage, 2002.

[2] E. Maharani, “Anak-Anak Pengguna Internet Terus Bertambah,” Republika News Paper, 2016. .

[3] Nabilla, "Mewujudkan Kolaborasi Keluarga, Pemerintah, dan Duta Kekinian untuk Menunjang Pendidikan di Era Digital," www.bundabiya.com, 2018. . 
[4] Kumparan, "Psikolog: Media Sosial Bisa Memicu Perilaku Bullying," Kumparan, 2019. [Online]. Available: https://kumparan.com/millennial/psikolog-media-sosial-bisa-memicu-perilakubullying-1qs5OBafutX/full.

[5] CNN Indonesia, "Remaja Kerap Pakai Internet untuk Hiburan dan Media Sosial," 2019. [Online]. Available: https://www.cnnindonesia.com/teknologi/20190401154314-185-382628/remajakerap-pakai-internet-untuk-hiburan-dan-media-sosial.

[6] D. H. Hockenbury and S. E. Hockenbury, Discovering psychology. Macmillan, 2010.

[7] H. P. Santosa, "Buku Ajar Mata Kuliah Sosiologi Komunikasi," in EF Press Digimedia, Semarang, 2017.

[8] M. Shochib, "Pola asuh orang tua (Dalam membantu anak mengembangkan disiplin diri sebagai pribadi yang berkarakter)," Jakarta: Rineka Cipta, 2010.

[9] H. Jenkins, "Confronting the challenges of participatory culture: Media education for the 21st century. An occasional paper on digital media and learning," John D. Catherine T. MacArthur Found., 2006.

[10] M. S. Darwadi, "Media Baru Sebagai Informasi Budaya Global-Membudayakan Literasi Media Internet Pada Anak Dan Remaja," Komunikator, vol. 9, no. 1, 2017.

[11] P. Aufderheide, Media Literacy. A Report of the National Leadership Conference on Media Literacy. ERIC, 1993.

[12] J. J. Arnett, R. Larson, and D. Offer, "Beyond effects: Adolescents as active media users," J. Youth Adolesc., vol. 24, no. 5, pp. 511-518, 1995.

[13] N. Kurnia, E. Wendratama, W. M. Adiputra, and I. Poerwaningtias, Literasi Digital Keluarga: Teori dan Praktik Pendampingan Orangtua terhadap Anak dalam Berinternet. UGM PRESS, 2019.

[14] K. G. Esterberg, Qualitative methods in social research, no. 300.18 E8. 2002.

[15] C. Moustakas, Phenomenological research methods. Sage publications, 1994. 